\title{
THE MECHANISM OF HAIRINESS IN GOSSYPIUM
}

\section{GOSSYPIUM HIRSUTUM}

\section{J. H. SAUNDERS}

Agricultural Research Division, Department of Agriculture, Khartoum, Republic of the Sudan and Empire Cotton Growing Corporation

\section{INTRODUCTION}

Received I 2.iv.6r

HaIR on the vegetative parts of the cotton plant is important. With mechanical picking the amount of trash collected with the lint is greater if the leaves are hairy and its removal is more difficult. Where the cotton jassid (Empoasca spp.) is a potential pest, plants lacking hair are seriously damaged. Hence in the U.S.A. glabrous plants are selected, while in India and Africa the aim in breeding work is a good cover of hair.

The cotton breeding programme of the Sudan has for some years been concerned with the breeding of jassid-resistance into Sakel cotton, which is a long staple, high quality variety of the species G. barbadense. Sakel is glabrescent and therefore hairiness has had to be transferred to it from other strains. Part of the transference programme included hybridization with suitably hairy strains of $G$. hirsutum which carry the desired length and density of hair; a knowledge of the genetics of hairiness within hirsutum was therefore desired. Data from crosses within hirsutum are reported here.

\section{PREVIOUS WORK}

Important work on the inheritance of hair in Gossypium is reported in a series of papers by Knight and Sadd (1954a and 1954b) and Knight (1952, r 954 and 1955). Knight's paper (1952) contains a résumé of earlier work on both genetical findings and the relationship of hair to jassid-resistance. Briefly, studies of the genetics of cotton hairiness have resulted in conflicting conclusions. Some workers report single gene control and others have found that their results called for a multigene hypothesis. In nearly all cases segregating families were classified as "glabrescent" or "hairy", or "more hairy" and "less hairy", and usually in reference to one selected part of the plant.

Knight's work in transferences of hair from G. hirsutum, G. herbaceum, $G$. arboreum and Tanguis ( $G$. barbadense) to Sakel (G. barbadense) led him to the conclusion that all hairy types studied contained the same principal hairiness factor, to which he gave the symbol $\mathrm{H}_{1}$. Harland (1939) investigating the Hawaiian endemic species G. tomentosum found a clear single factor control for hair. Simpson (1947) reported an extremely densely hairy Upland, T6I I, which arose by mutation, 
and which also showed monogenic inheritance of the hairy character. Knight established by homology tests that the hairiness genes from G. tomentosum and T6 I I were allelic, and independent of $\mathrm{H}_{1}$; he gave the locus the symbol $\mathrm{H}_{2}$.

Throughout his investigation of $\mathrm{H}_{1}$ Knight was aware that this gene alone could not account for all the hairiness of plants and referred to it as a " trigger-gene" or " key-gene" so that modifiers and minor genes working with $\mathrm{H}_{1}$ enhance density. In Sakel hairiness he examined the lower surface of the leaf and classified the plant as either "glabrescent" or "hairy". In some of his material he found it necessary to add an "intermediate" class. Stem hairiness was not described since in most Sakels ( $G$. barbadense) to which hairiness had been added the stems were glabrous or nearly so.

The distribution of hair and its density differs between strains and it is therefore important to examine the kinds of hairiness that are found before attempting to analyse the mechanism of hairiness. Balls (1912) distinguished between hair found on vegetative parts of the plant and hair found on the calyx, corolla and young boll. Harland (1939) says of an inter-Upland (G. hirsutum) segregation for corolla hairs, ". . . Segregation in the grade of hairiness of other parts of the plant was of the blending type, and it became evident that seed fuzz, amount of lint per seed (lint index), corolla hairiness and calyx hairiness are all part of one general hairiness mechanism". There are many instances in the literature of a relation between the hairiness of a plant and the quality and length of lint. Zaitzev (I934) pointed out that Old World cottons show hairiness in two layers and New World cottons in one only. This two-layered character was investigated by Saunders (1959) for the Old World diploid $G$. anomalum and a singlegene suppressor was found to control the relative density of the two layers.

Further, the type of hair found may be simple and single as is found in boll hairiness (whether associated with $\mathrm{H}_{1}$ or $\mathrm{H}_{2}$ ), or stellate as found on the vegetative parts of the plant. In the New World tetraploids these stellate hairs usually have $2-4$ arms whereas diploid forms often have 4-8 and one isolated form of herbaceum was reported as having IO-I 2 arms.

The Empire Cotton Growing Corporation maintains a world collection of cottons, of which 852 belong to the seven races of $G$. hirsutum (Hutchinson, 195I). These have been examined by the writer and classified for hair distribution and length. Hair distribution patterns fell into definite types: a type hairy on all vegetative parts, a type with glabrous or glabrescent laminae but hairy on stem and other vascular surfaces, a type hairy on the upper vein surfaces only and finally a completely glabrous type. The latter was found only in race palmeri. Out of $5 \mathrm{I}$ accessions of palmeri 49 were glabrous and the remaining 2 had only occasional hair on the vascular tissues. The combination of glabrous stem and hairy leaf is unknown for strains 
of G. hirsutum. Yet synthetic hairy Sakels are usually of this type whether the hair has been derived from $G$. hirsutum or Tanguis ( $G$. barbadense).

The other characteristics of hairiness show great variability between strains and species. Firstly, density of hair cover can range from a thick felt to a surface bearing only an occasional hair. Secondly, hair length can vary from about $2 \mathrm{~mm}$. down to less than $\mathrm{O}$ I $\mathrm{mm}$. Detailed studies of the actual numbers and length of hairs per unit area of leaf were made by Parnell, King and Ruston (1949). Segregation for density and length can occur at the same time although extreme density is usually accompanied by shortness of hair.

Full understanding of all these facets of the character " hairiness" is far from being achieved. Nevertheless, clarification of any part of the complex by genetic study is an aid to breeding programmes in which hairiness is of importance.

\section{METHODS}

The studies presented in this paper are restricted to hairs on the lower surface of the leaf lamina, (hereinafter referred to as LLL) and on the petiole and stem (referred to as stem). Density alone is considered and the degree of hairiness is defined in terms of nine standard grades set up for the purpose and illustrated in fig. I.

The matching of all the material against these standards was done by the same observer (the writer) and, although subjective, a satisfactory standard of consistency was maintained.

Control rows of parent hairy strains were planted generously amongst the experimental material as a check on environmental effects upon density. No density differences were observed between parental control lines.

Both LLL and stem hairiness are important for an understanding of the genetics of hairiness and the two have been presented together in correlation diagrams. A comparison of family distributions is also necessary in matching similarities or describing differences. For this reason most of the data have been converted to percentage frequencies correct to the nearest whole number, and in consequence family totals are often not one hundred exactly. The number of plants in each family is indicated with each diagram.

0
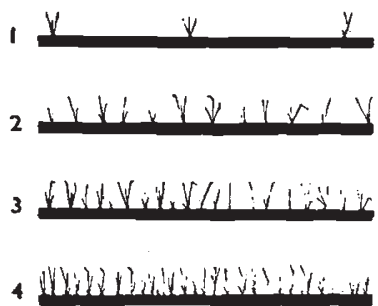

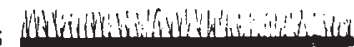

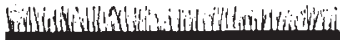

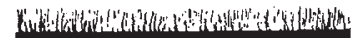

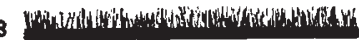

FIG. I.

The grading was carried out by holding the leaf, plucked from the plant, folded in such a way that a line of lamina hairs is seen in profile. Similarly the vascular surfaces seen side-on tend to present a linear appearance. However, it must be remembered that with increase in density the numbers of hairs increase quadratically in spite of the fact that visual assessment of grade is made on a linear appearance. Therefore from about grade 3 onwards hair numbers per unit area increase enormously.

The grade of any plant is given by two figures separated by a solidus, thus $3 / 4$ indicates an LLL grade of 3 and a stem grade of 4 . The symbol $0 / 0$ indicates no hairs on the two surfaces studied; it does not indicate a glabrous plant, this term 
being reserved for a plant entirely without hair on upper surface of leaf lamina and main vein also. The term glabrescent describes plants of grades $I$ and 2 . Fully hairy implies at least as hairy as the hairy parent strain.

\section{DESCRIPTION OF STRAINS}

Four strains of $G$. hirsutum race latifolium were used. Three of these carry long dense hair on all vegetative parts and are immune from jassid attack. These are: MU8b, a selection made by J. B. Hutchinson in India from the Malwa crop; Philippines Ferguson and Kapas Purao, two types from the Philippines and phenotypically indistinguishable. The fourth, UA2-20, an Acala strain from California, U.S.A., has very sparse long hair on the stem only and has no resistance to jassid attack.

T.S. 2, a strain of the race punctatum collected by H. E. King from the Lake Chad region of Northern Nigeria was used as the basic glabrous type since it lacks hair on all vegetative parts. It has no resistance to jassid attack.

\section{RESULTS}

The four hairy latifolium strains were crossed to the glabrous punctatum T.S. 2. The $\mathbf{F}_{\mathbf{1}}$ 's were graded and found to be uniform, selected plants were self-bred and $F_{2}$ families raised and graded. There were no large differences within each group of $F_{2}$ families and the data for each group were therefore bulked. Correlation diagrams of LLL and stem hair densities for the bulked $\mathrm{F}_{2}$ 's are given in fig. 2 . The average $F_{1}$ parent plant grade is indicated by a square on the correlation diagram.

Under field conditions MU8b can be seen to be rather more densely hairy than Ferguson or Kapas Purao. The $\mathrm{F}_{\mathbf{1}}$ parent plant values reflect this difference, MU8b $\times$ T.S. 2 being $3 / 4$, and Ferguson $\times$ T.S. 2 and Kapas Purao $\times$ T.S. 2 both being $2 / 3$. The difference in the hair density factors possessed by the three strongly hairy strains is more apparent in the $\mathrm{F}_{2}$ distributions. Where MU8b is the hairy parent (fig. 2, diagram I) a greater proportion of plants are in the higher density grades than in $\mathrm{F}_{2}$ 's with hairy parents Ferguson and Kapas Purao (fig. 2, diagrams 2 and 3). Ferguson and Kapas Purao are almost identical in their $F_{2}$ frequency distributions and MU8b does not differ from the other two in LLL density distribution but in stem hairiness. The $\mathrm{F}_{2}$ correlation diagram for UA2-20 $\times$ T.S. 2 (fig. 2, diagram 4) contrasts weakly and strongly hairy strains.

Knight (1952) and Knight and Sadd (I954b) demonstrated in hair transference to $G$. barbadense that each of the three strongly hairy strains used here contained a major hairiness gene $\mathrm{H}_{1}$. In none of the $\mathrm{F}_{2}$ distributions is there the discontinuity to be expected on the segregation of a major gene. It is not until the $F_{3}$ generation and backcrosses to the glabrous parent have been selfed that there is clear evidence of the segregation of a single gene of major importance. 


\section{(i) Evidence for a major hairiness gene}

$\mathrm{F}_{3}$ families were raised from selected plants, fully hairy, glabrescent or glabrous-leaved but with stems hairy, and finally, glabrous. It was expected that true-breeding types would be obtained from each class. Fully hairy and glabrous plants mostly provided true-breeding families but those with hair only on the stem were found to segregate giving a percentage of fully hairy plants.

In the transference of hair from $G$. hirsutum to $G$. barbadense (Sakel) true-breeding families with or without stem hair were obtained; this did not occur in the material reported here; stem hair was always present.

The self-bred progenies are set out in correlation diagrams in figs. 3, 4 and 5 for hairy parents MU8b, Ferguson and Kapas Purao respectively. As in the $F_{2}$ diagrams the hairiness grade of the parent plant of each family is given by a square at the appropriate value on

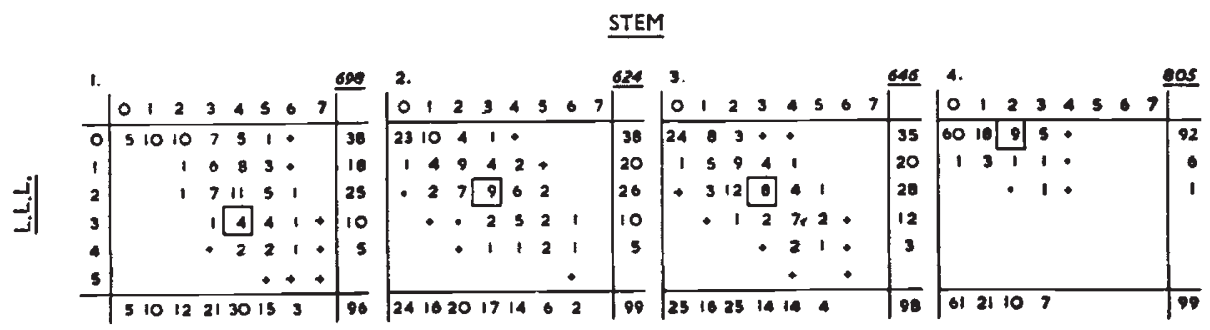

FIg. 2. $-F_{2}$ Families. 1. MU8b $\times$ T.S.2-Bulk of 5 families. 2. Ferguson $\times$ T.S.2-Bulk of 5 families. 3. Kapas Purao $\times$ T.S.2-Bulk of 5 families. 4. UA2-20 $\times$ T.S.2-Bulk of 10 families. The underlined italicised figures are bulk family totals of plants per group. + indicates less than $1 \%$ frequency.

the diagram. An examination of these families (see table I) shows that certain of them have clear discontinuity in their distributions occurring at the glabrescent end of the scale with approximately a quarter of the plants in grade $o / 0$ and three-quarters in the hairy grades.

Clearly in these families a major hairiness gene is segregating since all are good approximations to a ratio of I glabrescent to 3 hairy expected for a dominant hairiness gene. Further in two of these families the distribution has a distinct ratio of $\mathrm{I}: 2: \mathrm{I}$. These families

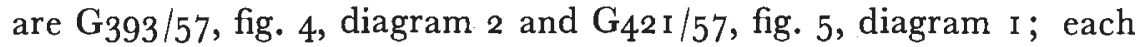
is further divided at grade 4 for stem hair.

There are other families which show similar discontinuity of distribution but which do not give very good approximations to the I : 3 segregation. These are given below in table 2 .

It will be seen that these aberrant families agree in giving ratios which approximate very closely to I glabrescent to 2 hairy. In the case of the MU8b data the shortage of plants in the hairy class might be ascribed to loss due to chlorophyll deficient plants since these were recorded in the $\mathrm{F}_{2}$ families. However, it is uncertain that in MU8b chlorophyll deficiency is linked to $\mathrm{H}_{1}$ or that this linkage in 
either phase affects the segregation of hairiness (Knight, I954). In the case of the Ferguson family $\mathrm{G}_{394 / 57}$ this cannot apply since no chlorophyll deficients were recorded in the cross with T.S. 2. These so-called distorted ratios may be no more than random deviations

STEM

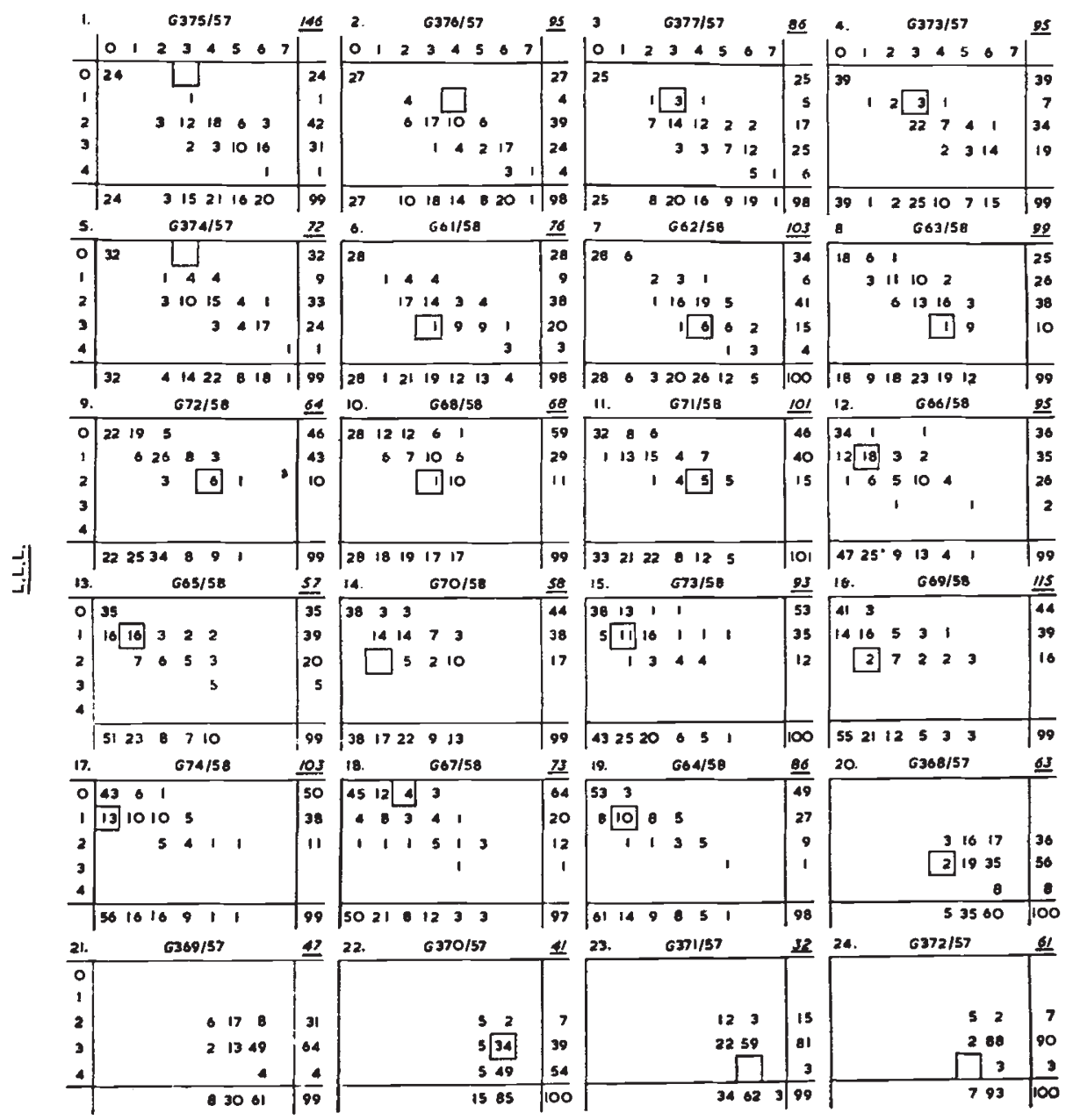

FIG. 3.-MU8b $\times$ T.S.2 F 's (diagrams I-5 and 20- 24). (MU8b $\times$ T.S.2) $F_{2} \times$ T.S.2) $F_{2}$ 's (diagrams 6*19).

from a single gene expectation but their uniformity argues against this and supports the hypothesis that the cause is genetic.

The Kapas Purao data provide another type of discontinuous family where the number of segregates in the glabrescent class is fewer than would be expected from a single gene segregation. These families are given in table 3 .

Here again it seems unlikely that these two families coincide by 


\section{STEM}

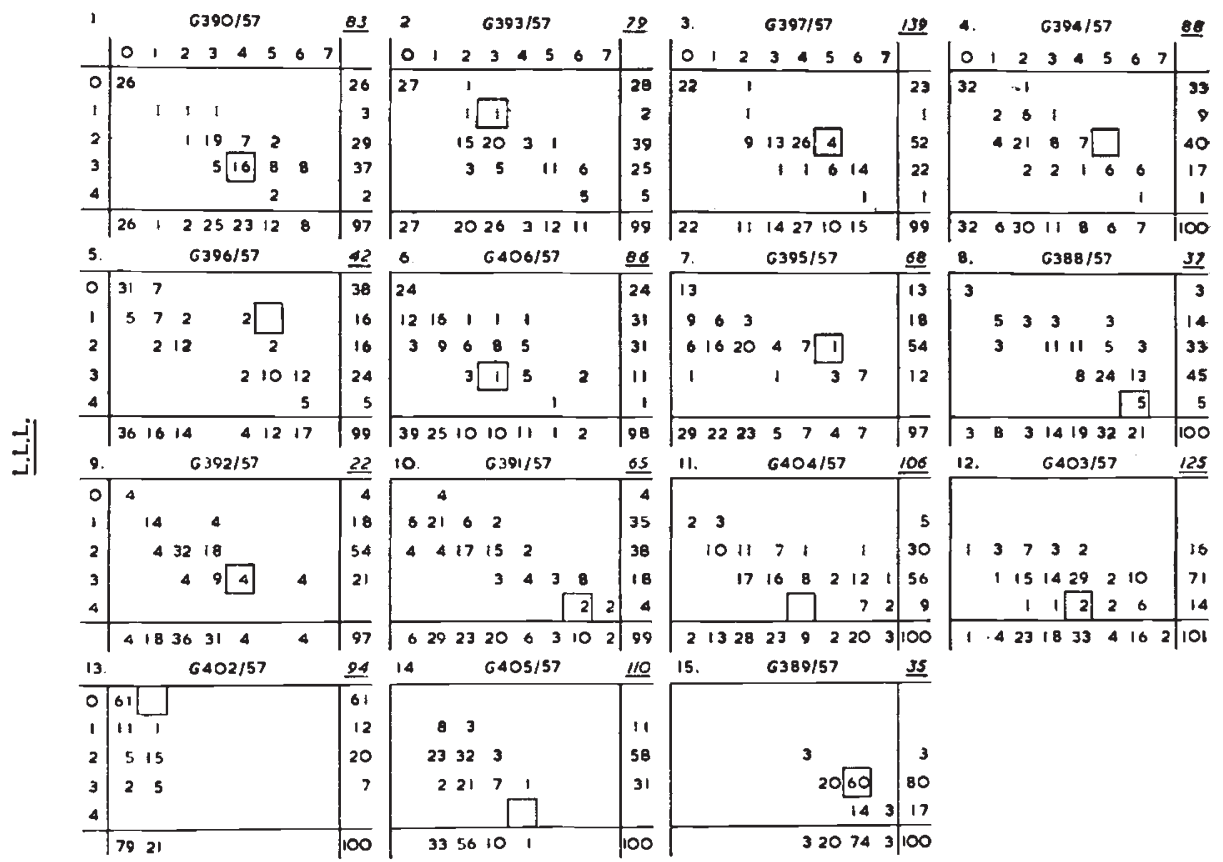

FIG. 4. - Ferguson $\times$ T.S.2 $F_{3}$ families. The underlined italicised figures are the numbers of plants per family.

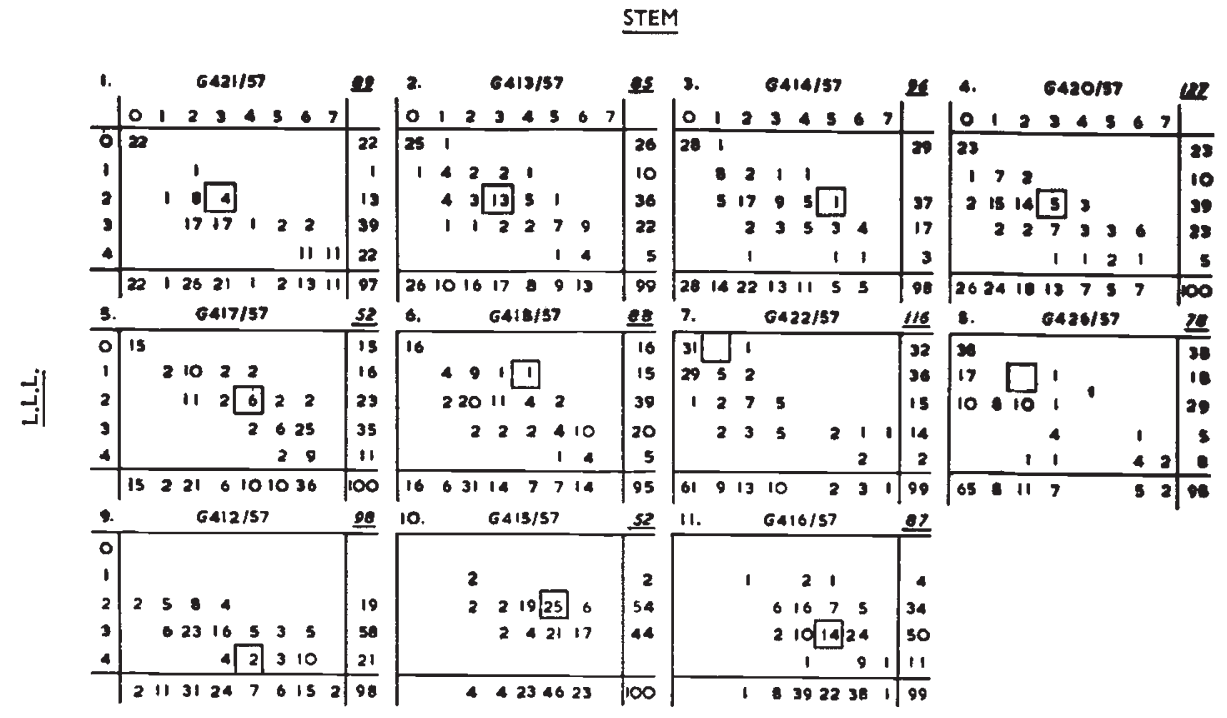

FIG. 5.-Kapas Purao $\times$ T.S.2 $F_{3}$ families. The underlined italicised figures are the numbers 
TABLE I

Families demonstrating the segregation of a dominant hairiness gene

\begin{tabular}{|c|c|c|c|c|}
\hline & \multirow{2}{*}{ Diagram } & \multirow{2}{*}{ Family } & \multicolumn{2}{|c|}{ Percentage } \\
\hline & & & Glabrescent & Hairy \\
\hline$\stackrel{\text { Fig. } 3}{\text { MU }} 8 \mathrm{~b} \times$ T.S. $2 \mathrm{~F}_{3}$ & $\begin{array}{l}1 \\
2 \\
3\end{array}$ & $\begin{array}{l}\mathrm{G}_{375 / 57} \\
\mathrm{G}_{376 / 57} \\
\mathrm{G}_{377 / 57}\end{array}$ & $\begin{array}{l}24 \\
27 \\
25\end{array}$ & $\begin{array}{l}75 \\
71 \\
73\end{array}$ \\
\hline$\left(M U 8 b \times\right.$ T.S. 2) $F_{2} \times$ T.S. 2) $F_{2}$ & 6 & G6r $/ 5^{8}$ & 28 & 70 \\
\hline $\begin{array}{l}\text { Fig. } 4 \\
\text { Ferguson } \times \text { T.S. } 2 \mathrm{~F}_{3}\end{array}$ & $\begin{array}{l}1 \\
2 \\
3\end{array}$ & $\begin{array}{l}\mathrm{G} 390 / 57 \\
\mathrm{G} 393 / 57 \\
\mathrm{G} 397 / 57\end{array}$ & $\begin{array}{l}26 \\
27 \\
22\end{array}$ & $\begin{array}{l}71 \\
72 \\
77\end{array}$ \\
\hline $\begin{array}{l}\text { Fig. } 5 \\
\text { Kapas Purao } \times \text { T.S. } 2 F_{3} \text {. }\end{array}$ & I & $\mathrm{G}_{421 / 57}$ & 22 & 75 \\
\hline
\end{tabular}

TABLE 2

Families with aberrant ratios for hairiness gene

\begin{tabular}{|c|c|c|c|c|}
\hline & \multirow{2}{*}{ Diagram } & \multirow{2}{*}{ Family } & \multicolumn{2}{|c|}{ Percentage } \\
\hline & & & Glabrescent & Hairy \\
\hline $\begin{array}{l}\text { Fig. } 3 \\
\text { MUU } 8 \mathrm{~b} \times \text { T.S. } 2 \mathrm{~F}_{3}\end{array}$ & $\begin{array}{l}4 \\
5\end{array}$ & $\begin{array}{l}\mathrm{G}_{373 / 57} \\
\mathrm{G}_{374 / 57}\end{array}$ & $\begin{array}{l}39 \\
32\end{array}$ & $\begin{array}{l}60 \\
67\end{array}$ \\
\hline$(\mathrm{MU} 8 \mathrm{~b} \times$ T.S. 2$) \mathrm{F}_{2} \times$ T.S. 2) $\mathrm{F}_{2}$ & 7 & $\mathrm{G} 62 / 58$ & 34 & 66 \\
\hline $\begin{array}{l}\text { Fig. } 4 \\
\quad \text { Ferguson } \times \text { T.S. } 2 F_{3}\end{array}$ & 4 & $\mathrm{G}_{394 / 58}$ & 32 & 68 \\
\hline
\end{tabular}

TABLE 3

Hairiness segregation in Kapas Purao

\begin{tabular}{|c|c|c|c|c|}
\hline & \multirow{2}{*}{ Diagram } & \multirow{2}{*}{ Family } & \multicolumn{2}{|c|}{ Percentage } \\
\hline & & & Glabrescent & Hairy \\
\hline $\begin{array}{l}\text { Fig. } 5 \\
\text { Kapas Purao } \times \text { T.S. } 2 F_{3} \text {. }\end{array}$ & $\begin{array}{l}I \\
2\end{array}$ & $\begin{array}{l}\mathrm{G}_{41} 17 / 57 \\
\mathrm{G}_{4} 18 / 57\end{array}$ & $\begin{array}{l}15 \\
16\end{array}$ & $\begin{array}{l}85 \\
79\end{array}$ \\
\hline
\end{tabular}


chance at these values widely removed from expectation. If two genes for hair initiation were segregating, one dominant and the other recessive, I9.5 per cent. of plants would appear in the glabrescent class. The observed figure is closer to this expectation than to the 25 per cent. expected for a single gene segregation. However, there is no supporting evidence for the second recessive gene. If such a gene existed it should initiate hair production when alone in the homozygous phase. It could be detected by selfing glabrous plants from the type of segregating family under discussion. If any of these plants were heterozygous for this gene their progeny should contain 3 glabrous to I hairy plants. In the course of this study many glabrous plants from segregating progenies derived from all three hairy parents were self-bred and in no case was such a family recorded.

Many other families occurred where segregation for hairiness was recorded over a range similar to that found in families demonstrating a discontinuity of distribution but with no similar division at any point. In the data where MU8b is the hairy parent (fig. 3, diagrams 8-19) a graded series of families of the blending type can be seen where in each subsequent family more and more plants are found at the glabrescent end of the scale. These families are all selfed progenies, the parents of which came from the backcross of the $F_{2}$ to the glabrous T.S. 2. If in the backcross to the glabrous parent dilution of factors favourable to hair production occurred this may have resulted in the telescoping of hairy segregates towards glabrescence in the subsequent self-bred generation.

Other families not conforming to the straightforward single gene pattern occur in the Ferguson and Kapas Purao material but are not strictly comparable with the MU8b families just discussed. Fig. 4 diagrams $5^{-12}$, give Ferguson $\times$ T.S. $2 \mathrm{~F}_{3}$ 's and fig. 5 diagrams 7-9 give Kapas Purao $\times$ T.S. $2 F_{3}$ 's. A wide range of self-bred progeny distributions is found. The Ferguson derivatives in fig. 4 are a graded series comparable with some MU8b families. G396/57 (diagram 5) is the least hairy; the families increase in hair density to $\mathrm{G}_{404 / 57}$ and $\mathrm{G}_{403 / 57}$ (diagrams II and I2) where the leaves have a high order of hair density, glabrescence being absent, and the main variability is on the stem alone. G396/57 (diagram 5) is unusual in that there is a clear division in stem hair distribution at grade " 3 " giving a ratio of 2 less hairy to I more hairy, an unexpected distribution, particularly in view of the fact that the parent plant graded $\mathrm{I} / 5$. $\mathrm{G}_{402 / 57}$ (diagram I3) is also unusual in so far as some variation in LLL hair occurs while stem hair is almost non-existent; the parent plant was virtually glabrous at o/I. G405/57 (diagram I4) is a uniform family which lacks high density genes as can be seen if it is compared with $\mathrm{G}_{389} 8 / 57$ (diagram I5).

The Kapas Purao derivatives are given in fig. 5. $\mathrm{G}_{422}$ and

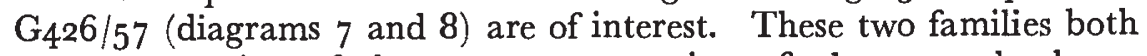
show telescoping of the greater proportion of plants to the lower 
densities as was remarked in the MU8b data. There is, however, a difference; in the higher grades there is an isolated group of very hairy plants, comprising 6 per cent. of the population in $\mathrm{G}_{422 / 57}$ and 7 per cent. in $\mathrm{G}_{426} 6 / 57$. In a $\mathrm{I}_{5}$ : I two-gene segregation the ratio expressed as a percentage would be $93.5: 6.5$. It is apparent that two genes are segregating. They may be two hairiness genes or

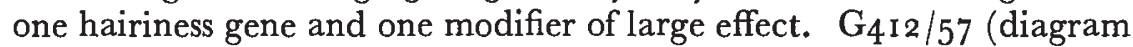
9 ) is segregating for stem factors only and is strictly comparable with $\mathrm{G}_{404}$ and $\mathrm{G}_{403 / 57}$ (fig. 4, diagrams I I and I2) in the Ferguson data. $\mathrm{G}_{4} \mathrm{I} 5$ and $\mathrm{G}_{4} \mathrm{I} 6 / 57$ (diagrams Io and II) may be regarded as families where the main gene is homozygous since no glabrous segregates are present, but where other modifying factors are segregating affecting the general level of density and thus giving the family a wide range of types. In the MU8b data on the other hand $F_{3}$ families $G_{3} 68$, $\mathrm{G}_{369}, \mathrm{G}_{370}$ and $\mathrm{G}_{372 / 57}$ (fig. 3, diagrams 20-24) are fully hairy families with far less variability. Even so there are recognisable differences in density level which are consistent with the grade of the parent plants. One Ferguson $\mathrm{F}_{3}$ of this type, i.e. of low variability, is $\mathrm{G}_{3} 89 / 57$ (fig. 4, diagram I5).

To summarise the evidence from the three strongly hairy hirsutums, all $\mathrm{F}_{2}$ families were of a continuous type of distribution, but certain $F_{3}$ families from them gave clear monofactorial ratios, indicating the existence of major hairiness genes. The possibility of a second recessive hairiness gene was indicated in some families but no support for this was found in breeding tests; a second gene with a large effect, probably a modifier, was apparent in two families. The wide range of family type occurring makes it abundantly clear that the hairiness character is complex and that its polygenic component is of great importance.

\section{(ii) Modifiers}

The existence of modifiers of large effect and others of small but additive effect was inferred from the family distributions. It was decided that a direct test could be made by taking glabrous plants at random from the self-bred progenies (MU8b $\times$ T.S. 2) $\mathrm{F}_{2} \times$ T.S. 2) $\mathrm{F}_{2}$ of plants out of the backcross families and crossing them to MU8b. A comparison of the results with the $F_{1}$ hair status of the initial cross between MU8b and T.S. 2 should reveal any difference in modifier content between the glabrous selection and T.S. 2. The data are too extensive to be fully presented in correlation diagrams and are given instead in fig. 6 as percentage frequency histograms for LLL and stem of each family. The plants may be arranged in six groups as in table 4 .

Each of the glabrous selections was also self-bred and none gave hairy progeny. An examination of fig. 6 shows that no family was as good as the $F_{1}$ at grade $3 / 4$ and all were certainly more variable. Group VI was the nearest to the $F_{1}$ standard but was no better than 
grade 2 for LLL hair. The glabrous selections were therefore less favourable to hair density in hybridisation than the glabrous punctatum T.S. 2.

These test families could be classified as having High or Low Density levels or as segregating families. Differences within the broad classification of high or low warrant further subdivision as

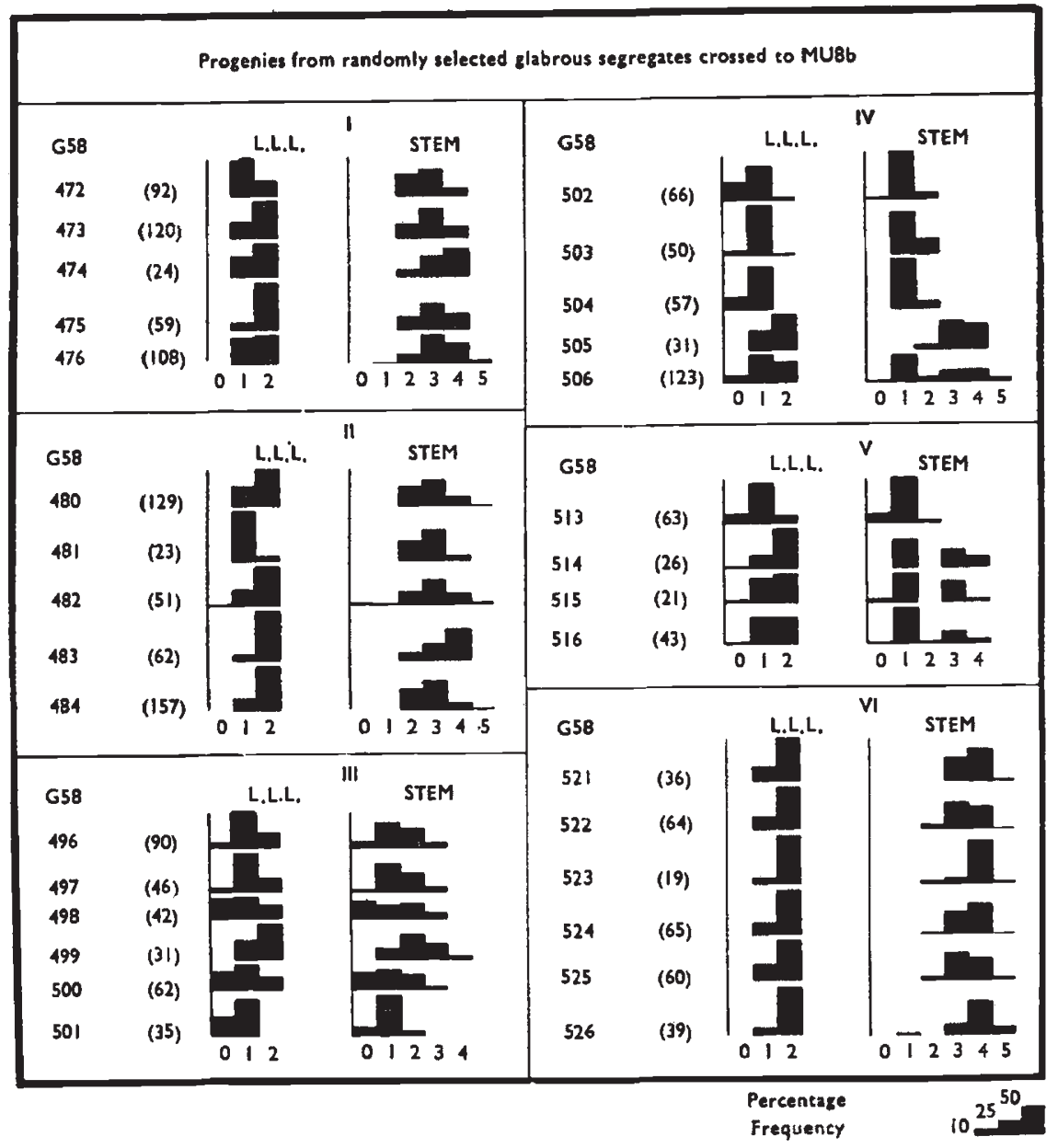

Fig. 6.-Percentage frequency histograms of hair densities of Lower Leaf Lamina and Stem of families from randomly chosen glabrous selections out of MU8b $\times$ T.S.2 derivatives backcrossed to MU8b. The number of plants per family is given in brackets.

+ or - While these differences can be seen in the frequency histograms of fig. 6 they are more clearly apparent in family correlation diagrams which were used in the assessment but are not included here. The summary in table 5 is derived from a comparison of families.

The six density classes given above are of course arbitrary and only serve to illustrate the wide range of family type that emerged on crossing randomly chosen glabrous plants to MU8b. That these 
differences are due to the differences between glabrous selections is demonstrated since MU8b which is common to all the backcrosses is known to be uniform with respect to hair density. In addition to this the original $F_{1}$ between MU8b and T.S. 2 was uniform and the sister $\mathrm{F}_{2}$ 's raised from this were also consistent among themselves. The four families from groups IV and V showing modifier segregation

TABLE 4

\begin{tabular}{|c|c|c|c|c|c|c|c|}
\hline $\begin{array}{c}\text { Group } \\
\text { I }\end{array}$ & Families & \multicolumn{6}{|c|}{$\begin{array}{l}\text { Derivation of glabrous selections } \\
\text { crossed to MU8b }\end{array}$} \\
\hline $\begin{array}{c}\text { I } \\
\text { II } \\
\text { III } \\
\text { IV } \\
\text { V } \\
\text { VI }\end{array}$ & $\begin{array}{l}\mathrm{G}_{472} \text { to } \mathrm{G}_{476 / 58} \\
\mathrm{G}_{480} \text { to } \mathrm{G}_{484} / 5^{8} \\
\mathrm{G}_{496} \text { to } \mathrm{G}_{501} / 5^{8} \\
\mathrm{G}_{502} \text { to } \mathrm{G}_{506 / 58} \\
\mathrm{G}_{513} \text { to } \mathrm{G}_{51} 6 / 5^{8} \\
\mathrm{G}_{521} \text { to } \mathrm{G}_{526 / 58}\end{array}$ & $\begin{array}{l}5 \\
5 \\
6 \\
5 \\
4 \\
6\end{array}$ & lan & 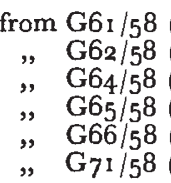 & $\begin{array}{r}\text { fig. } \\
\text { ", } \\
, " \\
, "\end{array}$ & $\begin{array}{l}\text { agra } \\
\text { ", } \\
\text { ", } \\
\text { ", }\end{array}$ & $\begin{array}{r}6) \\
7) \\
19) \\
13) \\
12) \\
11)\end{array}$ \\
\hline
\end{tabular}

are given in detail in table 6 . True plant populations for each family are used in these correlation tables.

If grade 2 for stem is taken as the point of minimum frequency and the numbers in that class are ignored, since they cannot be allocated to either group, the ratios in table 7 are obtained.

In three families a clear indication of a single modifier is to be

TABLE 5

Classification of families in fig. 6 for hair density

\begin{tabular}{|c|c|c|c|c|c|c|c|c|c|}
\hline \multirow{2}{*}{$\begin{array}{l}\text { Group } \\
\text { (fig. 6) }\end{array}$} & & \multirow{2}{*}{ Progeny of } & \multicolumn{6}{|c|}{ Family density leveI } & \multirow{2}{*}{$\begin{array}{c}\text { Modifier } \\
\text { segregation }\end{array}$} \\
\hline & & & $\mathbf{H}+$ & $\mathrm{H}$ & $\mathrm{H}-$ & $\mathrm{L}+$ & $\mathrm{L}$ & $\mathrm{L}-$ & \\
\hline I & G6I $/ 5^{8}$ & \multirow{6}{*}{$\begin{array}{l}\text { Glabrous selections } \\
\text { from these families } \\
\text { crossed to MU } 8 b\end{array}$} & I & 3 & I & . & . & . & . \\
\hline II & $\mathrm{G} 62 / 58$ & & I & 3 & I & . & . & : & : \\
\hline III & $\mathrm{G} 64 / 58$ & & & I & . & 2 & I & 2 & . \\
\hline IV & $\mathrm{G} 65 / 58$ & & I & . & . & . & 3 & . & I \\
\hline VI & $\mathrm{G} 66 / 5^{8}$ & & . & - & - & - & 1 & . & 3 \\
\hline & $G_{71 / 5^{8}}$ & & & & • & $\cdot$ & . & . & \\
\hline
\end{tabular}

$\left.\begin{array}{c}\mathrm{H}=\text { High density level } \\ \mathrm{L}=\text { Low density level }\end{array}\right\}$ with + or - , greater or lesser density.

found and in the fourth there is the probability of two modifiers segregating. It will be noted that $\mathrm{G}_{5} \mathrm{I} 6 / 59$ does not exceed the density range of the other three families and therefore they are probably heterozygous for one modifier and homozygous for the other. These results are consistent with the density levels found in the non-segregating families.

Two important inferences can be made from these data. Firstly the glabrous punctatum T.S. 2 must contain modifying genes favourable 
to enhanced density of hair since the $F_{1}$ of the cross MU8b $\times$ T.S. 2 is uniformly grade $3 / 4$ whereas the progenies of glabrous selections crossed to MU8b produced variable progeny all below the $F_{1}$ standard. Secondly the main hairiness gene $\mathrm{H}_{1}$, demonstrated by Knight (1952)

TABLE 6

Families demonstrating the segregation of modifiers

\begin{tabular}{|c|c|c|c|c|c|c|c|c|c|}
\hline & & \multicolumn{8}{|c|}{ Stem grades } \\
\hline & & & o & I & 2 & 3 & 4 & 5 & \\
\hline \multirow[t]{2}{*}{$\mathrm{G}_{506 / 5^{8}}$} & \multirow[t]{2}{*}{$\begin{array}{l}\text { LLL } \\
\text { grades }\end{array}$} & $\begin{array}{l}0 \\
1 \\
2\end{array}$ & $\begin{array}{l}\text { I } \\
. \\
\text {. }\end{array}$ & $\begin{array}{r}\mathrm{I} 5 \\
37 \\
7\end{array}$ & $\begin{array}{l}\dot{9} \\
.\end{array}$ & $\begin{array}{r}\dot{9} \\
\text { I } 3\end{array}$ & $\begin{array}{r}4 \\
20\end{array}$ & $\begin{array}{l}\text { I } \\
7\end{array}$ & $\begin{array}{l}16 \\
60 \\
47\end{array}$ \\
\hline & & & I & 59 & 9 & 22 & 24 & 8 & 123 \\
\hline \multirow[t]{2}{*}{$\mathrm{G}_{5^{14} / 5^{8}}$} & \multirow[t]{2}{*}{$\begin{array}{l}\text { LLL } \\
\text { grades }\end{array}$} & $\begin{array}{l}0 \\
1 \\
2\end{array}$ & : & $\begin{array}{l}I \\
6 \\
6\end{array}$ & . & $\dot{8}$ & $\dot{5}$ & : & $\begin{array}{r}\text { I } \\
6 \\
\text { I } 9\end{array}$ \\
\hline & & & . & I3 & . & 8 & 5 & . & 26 \\
\hline \multirow[t]{2}{*}{$\mathrm{G}_{515 / 58}$} & \multirow[t]{2}{*}{$\begin{array}{l}\text { LLL } \\
\text { grades }\end{array}$} & $\begin{array}{l}0 \\
1 \\
2\end{array}$ & I & $\begin{array}{l}1 \\
8 \\
2\end{array}$ & . & $\dot{8}$ & $\dot{b}$ & : & $\begin{array}{r}\mathrm{I} \\
9 \\
\text { I I }\end{array}$ \\
\hline & & & I & II & . & 8 & I & . & $2 I$ \\
\hline \multirow[t]{2}{*}{$\mathrm{G}_{516 / 5^{8}}$} & \multirow[t]{2}{*}{$\begin{array}{l}\text { LLL } \\
\text { grades }\end{array}$} & $\begin{array}{l}0 \\
1 \\
2\end{array}$ & $\begin{array}{l}\text { I } \\
\text {. }\end{array}$ & $\begin{array}{r}1 \\
19 \\
8\end{array}$ & I & $\dot{9}$ & $\dot{4}$ & : & $\begin{array}{r}I \\
2 I \\
2 I\end{array}$ \\
\hline & & & I & 28 & I & 9 & 4 & . & 43 \\
\hline
\end{tabular}

TABLE 7

\begin{tabular}{|c|c|c|c|}
\hline & Observed & \multicolumn{2}{|c|}{ Calculated } \\
\hline $\mathrm{G}_{5} \mathrm{06} / 5^{8}$ & $60: 54$ & $57: 57$ & $(\mathrm{I}: \mathrm{I})$ \\
\hline $\mathrm{G}_{514 / 58}$ & I3: 13 & 13:13 & $(1: 1)$ \\
\hline G515/58 & $12: 9$ & $10 \cdot 5: 10.5$ & $(I: I)$ \\
\hline $\mathrm{G}_{516 / 58}$ & $29: 13$ & $3^{1 \cdot 5}: 10 \cdot 5$ & $(3: 1)$ \\
\hline
\end{tabular}

to be present in MU8b, obviously depends for its full expression upon the residual genotype since in some of these families, notably group III, plants grading $\mathrm{I} / \mathrm{I}$ and less (including $\mathrm{o} / \mathrm{o}$ ) are recorded. All plants in these families must contain $\mathrm{H}_{1}$ by virtue of the cross to MU8b. The wide range of family type undoubtedly owes its variation to the modifier content of the glabrous selections. While modifiers 
of large effect have been shown to be present, the more subtle variations from family to family are no doubt due in a great measure to numerous genes of small individual effect.

(iii) Modifiers and $\mathrm{H}_{1}$

Finally certain plants from the test backcrosses just examined were self-bred. These " $\mathrm{F}_{2}$ " type families can be compared with the original $\mathrm{F}_{2}$ distribution for $\mathrm{MU} 8 \mathrm{~b}$ (fig. 2, diagram I). The parent plants were selected as follows:

5 plants grade $2 / 2$ or $2 / 2$ from $\mathrm{G}_{496 / 5^{8}}$

5 plants grade I/I or $2 / 3$ from $\mathrm{G}_{596 / 5^{8}}$ Group III, fig. 6

5 plants grade I/I or I $/ 2$ from $\mathrm{G}_{500 / 58}$ Group III, fig. 6

5 plants grade $2 / 3$ from $\mathrm{G}_{524} / 5^{8}$ Group VI, fig. 6

TABLE 8

Self-bred progenies of selected backcross plants of families shown in fig. 6

\begin{tabular}{|c|c|c|c|c|c|}
\hline \multirow{2}{*}{$\begin{array}{c}\text { Family } \\
\text { G/59 }\end{array}$} & \multirow{2}{*}{$\begin{array}{l}\text { Parent plant } \\
\mathrm{G}_{496} 6 / 5^{8}\end{array}$} & \multirow{2}{*}{$\begin{array}{l}\text { Parent plant } \\
\text { grade }\end{array}$} & \multicolumn{2}{|c|}{ Percentage } & \multirow{2}{*}{$\begin{array}{l}\text { No. of plants } \\
\text { per family }\end{array}$} \\
\hline & & & Glabrescent & Hairy & \\
\hline 307 &.$I$ & $I / I$ & \multicolumn{2}{|c|}{ continuous } & 45 \\
\hline 308 & .2 & $0 / 1$ & \multicolumn{2}{|c|}{ " } & $\begin{array}{l}43 \\
43\end{array}$ \\
\hline 309 & .3 & $I / I$ & \multicolumn{2}{|c|}{$"$} & 56 \\
\hline 310 & .4 & $\mathrm{I} / \mathrm{I}$ & \multirow{2}{*}{\multicolumn{2}{|c|}{$"$}} & $7 I$ \\
\hline 3 II & .5 & $I / I$ & & & 62 \\
\hline $3^{12}$ & .6 & $2 / 2$ & 29 & 71 & 66 \\
\hline $3^{1} 3$ & $\cdot 7$ & $1 / 3$ & 37 & $6_{3}$ & $3^{8}$ \\
\hline $3^{14}$ & .8 & $2 / 3$ & 29 & $7^{1}$ & $\sigma_{I}$ \\
\hline 315 & .9 & $2 / 2$ & II & 89 & 45 \\
\hline \multirow[t]{2}{*}{316} & . 10 & $2 / 2$ & I 7 & 83 & 65 \\
\hline & $\mathrm{G}_{5} 00 / 5^{8}$ & & & & \\
\hline $3^{17} 7$ & .1 & $I / I$ & I7 & $8_{3}$ & 73 \\
\hline 318 & .2 & $I / I$ & 23 & 77 & 39 \\
\hline $3^{19}$ & $\cdot 3$ & $\mathrm{I} / \mathrm{I}$ & \multirow{2}{*}{\multicolumn{2}{|c|}{34 continuous 66}} & 73 \\
\hline 320 & .4 & $I / I$ & & & 64 \\
\hline \multirow[t]{2}{*}{321} & .5 & $\mathrm{I} / \mathrm{I}$ & I9 & 81 & 64 \\
\hline & $\mathrm{G}_{524 / 5^{8}}$ & & & & \\
\hline $3^{23}$ & . I & $2 / 3$ & 23 & 77 & 79 \\
\hline 324 & .2 & $2 / 3$ & 26 & 74 & 46 \\
\hline 325 & $\cdot 3$ & $2 / 3$ & 25 & 75 & 56 \\
\hline 326 & .4 & $2 / 3$ & 26 & 74 & 55 \\
\hline 327 & .5 & $2 / 3$ & $3^{8}$ & 62 & 37 \\
\hline
\end{tabular}

The families obtained gave both continuous and discontinuous distributions. They are listed in table 8 with the percentage of plants glabrescent or hairy in those families where the two groups are distinct.

An example of each type of segregation is given in fig. 7 in percentage frequency correlation diagrams. Diagram $\mathrm{I}$ is a bulk of the data for families $\mathrm{G}_{30} 0$ to $\mathrm{G}_{3} \mathrm{I} / 59$, all low density families with no break in the distribution, and diagram 2 is a bulk of families $\mathrm{G}_{3} \mathrm{I}_{2}$ to $\mathrm{G}_{3} \mathrm{I} 6 / 59$ all of which show a clear division in distribution. Certain 
inferences can be drawn from the data of these 20 families. Firstly, they are all derived from plants heterozygous for $\mathrm{H}_{1} \mathrm{~h}_{1}$ since they were taken from backcross families obtained by crossing glabrous plants to MU8b (i.e. $h_{1} h_{1} \times H_{1} H_{1}$ ). All families are therefore segregating in respect of $\mathrm{H}_{1} \mathrm{~h}_{1}$ but only a proportion of them gave evidence of this in discontinuous distributions. In those families with continuous distributions therefore the effect of $\mathrm{H}_{1}$ is masked. A comparison of the two kinds of family show that the continuous type has the distribution of densities telescoped towards glabrescence, in particular on the stem. It seems probable that the shift in density values required to reveal the segregation of $\mathrm{H}_{1}$ is due to modifiers of large effect such as were demonstrated in the backcross material from which these families were derived. There is some support for this in the results obtained from the ro families derived from $\mathrm{G}_{49} 6 / 5^{8}$ and the 5 families

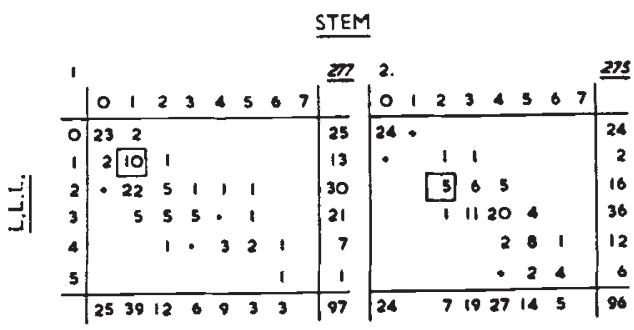

Fig 7.-Glabrous selections out of MU8b $\times$ T.S.2 derivatives backcrossed to MU8b and selfed.

I. Bulk of Low Density families $\mathrm{G}_{30}$ to $\mathrm{G}_{31}$ I $/ 59$. distribution.

2. Bulk of High Density families G312 to $\mathrm{G}_{316 / 59}$ showing discontinuous

The underlined italicised figures are bulk family totals of plants per group. + indicates less than $\mathbf{I} \%$ frequency.

derived from $\mathrm{G}_{524} / 58$, where the low grade parent (I/I) give a low density continuous progeny and the higher grade parent $(2 / 2$ or $2 / 3)$ gives the high density discontinuous. However, this is contradicted to some extent in the 5 families from $\mathrm{G}_{500} / 5^{8}$ where 4 of them were derived from low grade parents but gave discontinuous progeny.

Amongst the families clearly segregating for a major hairiness gene it is again observed that the ratios are not always in good agreement with expectation. The last group, $\mathrm{G}_{323}$ to $\mathrm{G}_{32} 7 / 59$, has 4 out of 5 families in close agreement with an expectation of 25 per cent. of plants in the glabrescent class but the fifth has 38 per cent. of plants in this class. The remaining 9 segregating families in the other two groups vary very widely. Once again it is felt that these extreme deviations must be due to genetic causes. Evidently the expression of the major gene $\mathrm{H}_{1}$ is very much dependent upon the residual genotype. In the extreme case the presence of the segregating genes $\mathrm{H}_{1} \mathrm{~h}_{1}$ cannot be detected in low density families due to the telescoping of the density values. 


\section{(iv) Hairiness in the absence of $H_{1}$}

It is appropriate after studying the components of hairiness in strongly hairy hirsutums to consider briefly the weakly hairy UA2-20. The bulk $\mathrm{F}_{2}$ of the cross between this strain and T.S. 2 is shown in fig. 2, diagram 4. There is no evidence here of any single hairiness gene initiating hair production. Tests were also made by crossing UA2-20 to glabrous selections, known from the work with MU8b to be carrying modifiers; $F_{2}$ type families were raised. In none of these test families did the level of hairiness differ from the original $F_{2}$ nor was there any discontinuity in distribution to suggest the presence of a gene of large effect. These results suggest that either modifiers of large effect do not respond to polygenic backgrounds of low threshold value or that this type of modifier acts only in conjunction with a major hairiness gene such as $\mathrm{H}_{1}$ which in all probability is absent from UA2-20.

\section{DISCUSSION}

This study of hairiness within the species hirsutum was intended to provide additional information concerning the mechanism of that character beyond the established presence of the key-gene $\mathrm{H}_{1}$ (Knight, see section 2). The use of the most hairy hirsutums hybridised with the glabrous race punctatum might be expected to reveal in segregating progenies some part of this mechanism. It can be seen from the results reported here that this is complex; a wide range of family type being obtained in the $\mathrm{F}_{3}$ and later generations. This may be contrasted with the behaviour of families segregating for the hairiness gene $\mathrm{H}_{2}$. At the time that the hairy strains carrying $\mathrm{H}_{1}$ were crossed to T.S. 2, Simpson's T6 I c carrying $\mathrm{H}_{2}$ was also crossed to T.S. 2. The $\mathrm{F}_{2}$ and subsequent generations showed a clear and unambiguous segregation into hairy and glabrous plants which confirmed the monogenic control of hair reported by Simpson (1947). Further the level of hair density in the presence of $\mathrm{H}_{2}$ was always high with little or no variation.

The hairiness conferred on strains carrying $\mathrm{H}_{1}$ is clearly different from the simple presence or absence of hair due to $\mathrm{H}_{2}$.

The function of $\mathrm{H}_{1}$ as a key-gene is confirmed, its presence being essential for any worthwhile cover of hairiness. The $F_{2}$ families contained a continuous range of hairy types and the segregation of $\mathrm{H}_{1}$ was not revealed by any break in the distribution. In subsequent generations certain families clearly gave ratios of 3 hairy to 1 glabrous plants. This is attributed to a reassortment of minor genes which had previously masked the effects of $\mathrm{H}_{1}$. It was also shown that full density levels are attained in the presence of major modifying genes acting upon $\mathrm{H}_{1}$.

However, $\mathrm{H}_{1}$ and its modifiers cannot initiate hair production without a suitable genetic background. This was demonstrated in plants which are known to carry $\mathrm{H}_{1}$ in the heterozygous state but which were virtually glabrous. Conversely genes favourable to hair 
production can be carried in glabrous strains but are not expressed in the absence of $\mathrm{H}_{1}$. The use of T.S. 2 as a basic glabrous type in this study was revealing in this respect.

The part played by polygenes in the expression of the hairiness character is of great importance. It must be inferred that the general genetic background of the plant which permits the expression of $\mathrm{H}_{1}$ is polygenic in nature. Density levels are clearly influenced to a great extent by numerous genes of small individual effect, hence the wide variety of family types as is seen in fig. 6 and tabulated in table 5 . Some polygenes are also specific since in some cases the LLL is influenced while the stem is not and in other cases the stem densities are more variable than the LLL. The multigene nature of the $\mathrm{H}_{1}$ hairiness complex clearly could confer great plasticity to that character.

These data on the mechanism of hairiness are of considerable importance for breeding work in circumstances where hairiness is a desirable characteristic of the crop. Especially is this so where hairiness has to be transferred onto a glabrescent commercial type from a hairy donor. It is quite clear that in order to breed a cotton with a dense enough cover of hair to achieve resistance to jassid many genes concerned with hair production must be brought together. These genes decide the distribution, length and density of hair. This might be done more simply by using $\mathrm{H}_{2}$, which is a stronger gene than $\mathrm{H}_{1}$; however, $\mathrm{H}_{2}$ is believed by Simpson (1947) to be associated with short lint, and would therefore be undesirable. Dark (I96o) reporting upon $\mathrm{H}_{2}$ in Sakel ( $G$. barbadense) found that this association could be broken, in which case this gene could be of value. However, there is less flexibility in the hairiness character as determined by $\mathrm{H}_{2}$.

In this study on the species hirsutum LLL hair and stem hair were nearly always strongly correlated and no plant was produced strongly hairy on the stem and not on the leaf or vice versa. In $G$. barbadense on the other hand strains with hair confined to the leaf have been bred following gene transferences from hirsutum. Studies on the components of hairiness distribution in these interspecific transferences will be described in a later paper.

\section{SUMMARY}

Densely hairy strains of $G$. hirsutum race latifolium were hybridised with a glabrous strain of race punctatum. From segregating progenies certain conclusions were drawn concerning the mechanism of hairiness within the species. It was clear that hairiness is a complex multigenic character with both major and minor genes concerned. In this study, only hair density was examined though length and distribution are equally important components which can vary independently of density. Certain types of gene action were noted:

(i) $\mathrm{H}_{1}$ is a hairiness gene of large effect which under favourable 
genotypic conditions greatly adds to the general level of hair density.

(ii) There are modifying genes, both major and minor, active only in the presence of $\mathrm{H}_{1}$ but capable of effecting considerable change in density level.

(iii) Low level hair density due to minor hairiness genes (e.g. UA2-20) occurs in the absence of $\mathrm{H}_{1}$. The level of hairiness of this complex is not raised by the addition of genes from (ii).

A search was made for any additional major hairiness genes other than $\mathrm{H}_{1}$ but none was found. The role of $\mathrm{H}_{1}$ in the hairiness complex was confirmed as that of a key-gene and the understanding of the part it plays was extended.

Acknowledgments.- My thanks are due to Professor Sir Joseph Hutchinson for reading the manuscript and giving helpful criticism and to the Chief of the Agricultural Research Division of the Sudan Republic for permission to publish this work.

\section{REFERENCES}

Balls, w. L. 1912. The Cotton Plant in Egypt (Ist Ed.). Macmillan, London.

DARK, s. o. s. Ig6o. Plant hairiness and staple length in cotton. Emp. Cott. Gr. Rev., 37, 206-269.

harland, s. c. 1939. The Genetics of Cotton. Jonathan Cape, London.

HUtchinson, J. B. I95I. Intra-specific differentiation in Gossypium hirsutum. Heredity, 5, 16 $1-193$.

KNIGHT, R. L. 1952. The genetics of jassid resistance in cotton. I. The genes $\mathrm{H}_{1}$ and $\mathrm{H}_{2}$. 7. Genet., 5I, 47-66.

KNIGHT, R. L. I 954 . The genetics of jassid resistance in cotton. IV. Transference of hairiness from Gossypium herbaceum to G. barbadense. F. Genet., 52, 199-207.

KNIGHT, R. L. I955. The genetics of jassid resistance in cotton. V. Transference of hairiness from Gossypium arboreum to G. barbadense. 7. Genet., 53, I50-1 53 .

KNIGHT, R. L., AND SADD, J. I954a. The genetics of jassid resistance in cotton. II. Pubescent T61 I. 7. Genet., 5I, 582-585.

KNIGHT, R. L., AND SADD, J. I954 $b$. The genetics of jassid resistance in cotton. III. The Kapas Purao, Kawanda punctatum and Philippines Ferguson group. J. Genet., 52, 186-198.

MAYR, E. I959. "Where are We?"-Genetics and 2oth Century Darwinism. Cold Spring Harbor Symposia on Quantitative Biology. 24, I-I4. New York.

PARNELL, F. R., KING, H. E., AND RUSTON, D. F. I949. Jassid resistance and hairiness of the cotton plant. Bull. Ent. Res., 39, 539-575.

saunders, J. H. 1956. Progress Reports from Experiment Stations; Sudan (1955-56), I4-15. Empire Cotton Growing Corporation.

SAUNDERS, J. H. 1959. Studies in wild species of cotton. I. Variation within Gossypium anomalum. Heredity, I3, 249-260.

simpson, D. M. I947. Fuzzy leaf in cotton and its association with short lint. $\mathcal{F}$. Hered., 38, I53-156.

zaItzev, G. s. 1924. A hybrid between Asiatic and American cotton plants Gossypium herbaceum L. and Gossypium hirsutum L. Bull. appl. Bot. Pl. Breeding, I3, I32-I 34 . 